Review

\title{
Thyroid hormone and growth : relationships with growth hormone effects and regulation
}

\author{
G. Cabello and C. Wrutniak
}

INRA-ENSA Montpellier, unité de différenciation cellulaire et croissance, 9, place Viala, 34060 Montpellier Cédex, France

(received 28 November 1988, accepted 5 September 1989)

Summary - For some years, research in the field of growth endocrinology has been mainly focused on growth hormone $(\mathrm{GH})$. However, it appears that $\mathrm{GH}$ does not always control growth rate. For instance, it does not clearly influence intra-uterine growth : moreover, although the results of GRF or GH administration appear convincing in rats, pigs or heifers, this is not the case in chickens and lambs. In addition, GH does not always clearly stimulate somatomedin production, particularly diring food restriction and fetal life, and in hypothyroid animals or sex-linked dwarf chickens. In such situations, this phenomenon is associated with a reduced T3 production, suggesting a significant influence of thyroid function on GH action, and more generally, on body growth. In fact, numerous data demonstrate that thyroid hormone is strongly involved in the regulation of body growth. In species with low maturity at birth, such as the rat. T4 and T3 affect postnatal growth eleven days earlier than the appearance of $\mathrm{GH}$ influence. In contrast to $\mathrm{GH}$, thyroid hormone significantly influences fetal growth in sheep. Moreover, the body growth rate is clearly stimulated by T3 in dwarf animals. In addition to its complex metabolic effects involved in the general mechanisms of body growth, thyroid hormone stimulates the production of growth factors, particularly EGF and NGF. Moreover, it affects $\mathrm{GH}$ and somatomedin production and also their tissue activity. All these results strongly suggest that it would be difficult to study $\mathrm{GH}$ regulation and physiological effects without taking thyroid function into account.

body growth - thyroid hormone - GH - GRF - IGF

Résumé - Hormones thyroïdiennes et croissance. Interactions avec l'axe somatotrope. Depuis plusieurs années, les recherches concernant l'endocrinologie de la croissance sont particulièrement orientées sur l'hormone de croissance (GH). II semble cependant que le GH ne contróle pas la croissance dans toutes les situations. Ainsi, elle ne semble pas influencer la croissance intra-utérine; de plus, si les résultats de l'administration de GRF ou de GH sont convaincants chez le rat, le porc ou le bovin, ils s'avèrent plus décevants chez le poulet ou le mouton. D'autre part, la GH n'induit pas toujours une stimulation de la production de somatomédines, notamment pendant la vie intra-utérine, au cours de la restriction alimentaire, ainsi que chez les animaux hypothyroïdiens et chez les poulets nains (nanisme lié au sexe). Dans toutes ces situations particulières, la déficience de stimulation des somatomédines par la GH est associée à une production réduite de $T 3$, ce qui suggère une influence significative de la fonction thyroidienne sur les effets de la GH, et plus généralement sur la croissance. En fait, de nombreux résultats 
démontrent que les hormones thryö̈diennes sont impliquées dans la régulation de la croissance corporelle. Chez les espèces à faible maturité à la naissance telles que le rat, la T4 et la T3 influencent la croissance postnatale bien avant que la GH ait un effet significatif. De plus, contrairement à la $\mathrm{GH}$, les hormones thyroïdiennes affectent la croissance foetale chez le mouton. D'autre part, la croissance corporelle est significativement stimulée par la T3 chez les animaux nains. En plus de leurs effets métaboliques complexes qui participent aux mécanismes généraux de la croissance corporelle, les hormones thyroïdiennes stimulent la production de facteurs de croissance tels que le NGF ou l'EGF. Elles influencent également la production de GH et de somatomédines, ainsi que leurs activités tissulaires. Tous ces résultats suggèrent qu'il serait difficile d'étudier la régulation de l'axe somatotrope et ses conséquences physiologiques, en particulier sur la croissance, sans tenir compte de la fonction thyroïdienne.

croissance corporelle - hormone thyroïdienne - GH - GRF - IGF

\section{INTRODUCTION}

Despite intensive work, the endocrine regulation of growth is still poorly understood. Pathological conditions such as acromegalia, growth hormone $(\mathrm{GH})$ deficiency and cretinism have shown the importance of $\mathrm{GH}$ and thyroid function. However, from embryonic life onward, all hormonal regulations are probably implicated at different levels and at different periods in the control of growth. The hierarchy of endocrine influences in this field has not been established, and studies of situations in which growth has stopped or has slowed down could provide some valuable information.

For some years, research in the field of growth endocrinology has been focused mainly on growth hormone, raising an important question : is the stimulation of $\mathrm{GH}$ and somatomedin production sufficient to increase body growth ? Numerous data do not agree with such a concept.

In this paper, we will first present some experimental facts suggesting that growth hormone cannot be considered alone in growth regulation, particularly in situations where T3 production is impaired. Secondly, we will discuss some significant data indicating the important role of thyroid function in this field. Lastly, mechanisms mediating the influence of thyroid hormones on growth will be reviewed, with special reference to the relationships between thyroid function and $\mathrm{GH}$ regulation.

\section{GROWTH HORMONE DOES NOT ALWAYS CONTROL GROWTH RATE}

Numerous observations have been reported suggesting that $\mathrm{GH}$ does not always have as decisive a role as expected in growth control.

\section{Fetal GH does not clearly influence intra-uterine growth}

The first argument is that growth hormone does not clearly control fetal body growth. In all animals studied such as mice (Eguchi, 1961) and rats (Jost, 1977), lack of circulating $\mathrm{GH}$, induced by decapitation, did not affect fetal growth. Moreover, the influence of pituitary destruction upon 
body growth is not detectable before the 25th day of extra-uterine life in rats (Walker et al., 1950), and is even more delayed in rabbits (Vézhinet, 1968).

In the fetal lamb, the situation needs some clarification. It is generally assumed that hypophysectomy, performed between days 100 and 112 of pregnancy in sheep fetuses, does not reduce the birthweight of lambs (Jones et al., 1985; Parkes, 1985). However, in similar experimental conditions, we have observed that fetal pituitary destruction was associated with a $30 \%$ reduction of the birthweight (Wrutniak et al., 1985). Hypophysectomy, like thyroidectomy, results in very low plasma thyroid hormone levels in lamb fetuses, and thyroidectomy induces a similar reduction of the birthweight (Hopkins \& Thorburn, 1972; Bhakthavathsalan et al., 1981) without suppression of the levels of other pituitary hormones or other hormones influenced by the pituitary. Therefore, in our opinion, the effect of hypophysectomy recorded in our work could be due to a thyroid hormone deficiency. However, in this hypothesis, the observation by other researchers that fetal pituitary destruction fails to affect intra-uterine growth, is not clear and needs further study.

It could be assumed that the influence of fetal GH on intra-uterine growth may be masked by a significant production of placental GH. Such a placental factor was identified in pregnant women by Frankenne et al. (1987). However, no evidence was provided that this $\mathrm{GH}$ could reach the fetus. Moreover, such a possibility does agree with the observation that rat and rabbit body growth is not sensitive to pituitary destruction before days 25 and 100 of extra-uterine life (Vézinhet, 1968; Walker et al., 1950).

\section{The varying effects of growth hormone releasing factor (GRF) or GH administration on postnatal growth}

GRFadministration is a convenient means of increasing plasma $\mathrm{GH}$ levels : after a single injection, hp GRF (1-44) $\mathrm{NH} 2$, or hp GRF (1-29) $\mathrm{NH} 2$ are equipotent in stimulating $\mathrm{GH}$ secretion in heifers or pigs (Petitclerc et al., 1987). However, the mode of administration is important : Kensinger et al. (1987) have shown that the administration of the same amount/ day of GRF is more effective in raising $\mathrm{GH}$ levels in lambs when performed using four to eight daily injections, than using only two injections or continuous infusion. Moreover, in steers, Moseley et al. (1984) have shown that the pulsatile administration of GRF is able to increase GH secretion without desensitization for at least 5 days. Therefore, bearing the mode of GRF administration in mind, the effects of $\mathrm{GH}$ and GRF administration upon body growth should be considered together.

GRF administration could be effective in improving body growth in rats. Pulsatile injections of GRF every $3 \mathrm{~h}$ for 12 days, increased the body growth of the young by $\approx 30 \%$ (Clark \& Robinson, 1985). On the other hand, Wehrenberg (1986) reported that the growth rate of rats was significantly decreased by chronic treatment with GRF antisera. However, continuous infusion (Clark \& Robinson, 1985), or GRF administration twice a day (Dubreuil \& Morisset, 1986), was without effect despite a significant rise in plasma $\mathrm{GH}$ levels. This suggests, as in other species, the significance of the mode of GRF administration.

$\mathrm{GH}$ has had a marked effect in pigs. Treatment with exogenous pituitary porcine GH (Boyd et al., 1986; Campbell et al., 1988; Chung et al., 1985; Etherton 
et al., 1986; 1987), or recombinant porcine GH (Evock et al., 1988), increases pig growth performance. Despite differences between studies, $\mathrm{GH}$ seems to increase the average daily gain from $10 \%$ to $20 \%$, and to improve feeding efficiency from $15 \%$ to $35 \%$.

In Belgian white blue heifers, subcutaneous $\mathrm{GH}$ injections, once a day for 8 weeks, increased weight gain by $21 \%$ and also feeding efficiency (Fabry et al., 1985; 1987). Moreover, Closset et al. (1986) reported that immunization against somatostatin was associated with an $11 \%$ improvement of body growth in young bulls of the same breed.

However, more negative than positive results have been reported in other animals. In chickens, Bowen et al. (1987) failed to observe a significant effect of chicken GH administration in three different lines. Leung et al. (1986) observed a slight positive influence of homologous $\mathrm{GH}$, or human GRF, administration on body growth, but this effect was very transient. Moreover, the results of Baile et al. (1985) did not show evidence of any effect of GRF administration despite a substantial rise in plasma $\mathrm{GH}$ levels.

Similarly in sheep, only Wagner \& Veenhuizen (1978) reported a significant influence of $\mathrm{GH}$ administration which was not recorded by Wheatley et al. (1966) or Muir et al. (1983). In addition, Pastoureau et al. (1988) did not observe an improved growth rate in hypotrophic or normal lambs receiving two daily injections of GRF. In this species, Bass et al. (1987) observed only a small growth response to somatostatin immunization.

\section{Growth hormone does not always stimulate somatomedin production}

Although growth hormone exerts direct metabolic effects, its major influence on growth is mediated by an increase in cell production of somatomedins. However, $\mathrm{GH}$ does not always stimulate somatomedin production. Although caution must be used in the interpretation of some results which do not take into consideration the pulsatile mode of $\mathrm{GH}$ secretion, it is generally agreed that such a phenomenon is apparent in at least four situations : food restriction, fetal life, sexlinked dwarfism and hypothyroidism. A better knowledge of the hormonal status encountered in these particular situations could provide interesting ways to study endocrine influences required for an optimal effect of $\mathrm{GH}$ on body growth.

Food restriction is associated with a rise in plasma $\mathrm{GH}$ levels in numerous species such as the ewe and its fetus (Koritnik et al., 1981), the chicken (Falconner et al., 1981) and man (Grant et al., 1973), whereas, somatomedin activity, or somatomedin-C/IGF1, are significantly decreased in plasma (chicken : Falconner et al., 1981; man : Grant et al., 1973; rat: Maes et al., 1986). This phenomenon could be explained by a reduction in the number of $\mathrm{GH}$ receptors, at least in the rat (Baxter et al., 1981; Postel-Vinay et al., 1982; Maes et al., 1986).

A similar dissociation between $\mathrm{GH}$ and somatomedin-C/IGF1 is apparent during intra-uterine life. After the 100th day of pregnancy, the plasma level of $\mathrm{GH}$ is about 10 times higher in the ovine fetus than in its mother (Basset et al., 1970; Bassett \& Gluckman, 1986; Lowe et al., 1986) and the secretion of this hormone is characterized by a markedly exaggerated pulsatile release (Gluckman, 1985); however, the plasma concentrations of IGF1 are very low (Gluckman \& Butler, 1985). Moreover, as decapitation did not influence plasma IGF1 levels (Gluckman, 1985), IGF1 production is not obviously dependent on $\mathrm{GH}$ regulation. The 
situation is the same in human fetuses, where plasma IGF1 levels are similar to those observed in adults with total $\mathrm{GH}$ deficiency (Lassare et al., 1986). At birth, the level of $\mathrm{GH}$ in neonates is about ten times higher than in adults, whereas, concentrations of somatomedin- $\mathrm{C}$ are five times lower (Nagashima et al., 1986). As in sheep, fetal IGF1 production does not seem to be regulated by $\mathrm{GH}$ secretion (Sara \& Carlsson-Skwirut, 1986).

In sex-linked dwarf chickens, plasma $\mathrm{GH}$ levels are also higher than in normal animals (Hoshino \& Yamamoto, 1977; Hoshino et al., 1982; Scanes et al., 1983; Huybrechts et al., 1987), but the levels of somatomedin $\mathrm{C}$ are lower (Hoshino et al., 1982; Huybrechts et al., 1985; 1987). This could be explained by a reduction in growth hormone receptor binding (Leung et al., 1987).

Hypothyroidism is associated with a comparable situation. If, in hypothyroid rats, plasma $\mathrm{GH}$ and IGF levels are significantly lowered, $\mathrm{GH}$ administration does not restore IGF1 concentrations (Burstein et al., 1979). Similarly, plasma levels of somatomedin- $C$ are decreased in hypothyroid chickens despite normal $\mathrm{GH}$ concentrations (Decuypère et al., 1987).

\section{T3 deficiency in situations in which GH does not increase somatomedin production}

In the preceding situations in which $\mathrm{GH}$ apparently does not increase somatomedin-C/IGF1 production, T3 deficiency simultaneously occurred.

In all animals studied, food restriction was associated with a considerable reduction of plasma T3 levels, such as in man (Burman et al., 1979; Marugo et al., 1984; Suda et al. 1978), calves (Blum \&
Kunz, 1981; Tveit \& Larsen, 1983) and adult (Blum et al., 1980) or newborn sheep (Wrutniak \& Cabello, 1987a). This decrease in $\mathrm{T} 3$ production could be explained not only by a lowered TSH secretion (Burger et al., 1981; Hugues et al., 1984; Röjdmark \& Nygren, 1983; Tveit \& Almlid, 1980; Wrutniak \& Cabello, 1987a), but also by an inhibition of the peripheral conversion of T4 into T3 (Balsam \& Ingbar, 1979; Chopra, 1980; Gavin \& Moeller, 1983).

In the ovine fetus, plasma T3 levels are very low during the major part of the pregnancy, in parallel with a reduced T3 thyroid secretion (Klein et al., 1980), and a marked inactivity of cellular 5'-deiodinases (Wu et al., 1986). They progressively rose only after the 130 th day of gestation (Klein et al., 1978; Wrutniak et al., 1985). Similarly, in the human fetus, T3 levels remain undetectable until the 30 th week of pregnancy and rise during the last 10 weeks. At birth, they are three times lower than those measured in the mother (Fisher et al., 1977).

As in the other situations, Scanes et al. (1983), May \& Marks (1983), Marsh et al. (1984) and Lauterio et al. (1986) have reported that plasma T3 levels decreased in sex-linked dwarf chickens. Moreover, Hoshino et al. (1986) have observed that, despite a large increase in plasma T4 levels after TRH administration, plasma T3 levels did not rise in these animals, suggesting a depressed T4 to T3 conversion. As in chickens growth hormone could induce stimulation of 5'-deiodinases (Kühn et al., 1986a, b); the diminished hepatic growth hormone binding reported in such animals (Leung et al., 1987) could be partly involved in this depression.

Therefore, in addition to hypothyroidism, the situations in which growth hormone does not increase somato- 
medin-C/IGF1 production are associated with T3 deficiency. Although this set of data must not be considered as a direct proof, it could suggest the existence of relationships between thyroid function and physiological effects of $\mathrm{GH}$. In particular, as is stressed in a following chapter, T3 could affect IGF1 production, and therefore, the stimulation of this production by $\mathrm{GH}$. Such a phenomenon could partly explain the subsequently presented effects of thyroid hormones on body growth.

\section{THYROID HORMONE STRONGLY INFLUENCES BODY GROWTH}

A great number of clinical or experimental observations underline the importance of thyroid function in the regulation of body growth.

\section{Dwarfism resulting from congenital hypothyroidism}

Like GH deficiency, congenital hypothyroidism, and particularly cretinism, is often associated with dwarfism. In contrast to mental retardation, this growth deficiency could be easily reversed by thyroxine administration (Utiger, 1979).

\section{Thyroid hormone influences the fetal growth}

In species with low maturity at birth, the fetal growth is apparently independent of thyroid function, as in the rabbit (Jost et al., 1958) or the rat (Cooke et al., 1984;
Jost, 1969; Jost \& Picon, 1970). However, no conclusion could be drawn from these results, as this endocrine function is immature during intra-uterine life. Plasma T3 levels are undetectable and T4 concentrations are slightly higher than the limit of detection of the radioimmunological assay near birth (Wrutniak \& Cabello, 1983). However, at least in the rat, iodinated hormones considerably affect postnatal growth after 12th - 14th days of life (at this age, plasma T3 levels have reached a maximum value), 11 days earlier than the appearance of the influence of $\mathrm{GH}$ (Bakke et al., 1976; Cooke et al., 1984; Kikuyama et al., 1974).

In species with a long gestation period, thyroid hormone influences fetal growth. In monkeys, radiothyroidectomy performed at mid-gestation (80 days) induced a slight but significant decrease in fetal weight $(\approx 10 \%)$, measured 70 days later (Holt et al., 1973; Kerr et al., 1972). Similarly, in the fetal lamb, a thyroid hormone deficiency, linked to poor maternal iodine intake, was associated with a $20 \%$ reduction in the birthweight (Setchell et al., 1960). This growth retardation was $>30 \%$, after a thyroidectomy performed around the 100th day of pregnancy (Bhakthavathsalan et al., 1981; Erenberg et al., 1973; Hopkins \& Thorburn, 1972). The only exception could be the human newborn in whom it is generally assumed that moderate congenital hypothyroidism does not appear to influence the intra-uterine growth.

Therefore, in contrast to $\mathrm{GH}$, thyroid hormones could be involved in fetal growth regulation, at least in late gestation in big mammals. In small mammals, which are less mature at birth, this influence seems to appear only after birth when thyroid function is well developed (this occurs at an earlier stage than that 
recorded for the onset of the influence of $\mathrm{GH}$.

\section{Thyroid hormone improves body growth in dwarf animals}

Fouchereau-Péron et al. (1981) have shown that in the dwarf mouse, growth could be stimulated by $\mathrm{T} 3$ and/or $\mathrm{GH}$ administration. However, the activation induced by $\mathrm{GH}$ was significantly lower than that observed after T3 administration. Moreover the effects of $\mathrm{T} 3+\mathrm{GH}$ were not greater than the influence of $T 3$ alone. As pituitary function is significantly impaired in dwarf mice, these data are in agreement with the results published by Scanes et al. (1986b) showing that T3, but not $\mathrm{GH}$, was able to restore the growth of hypophysectomized chickens.

In sex-linked dwarf chickens, Bowen et al. (1987) have observed that T3 supplementation could increase growth. According to these authors, the same treatment decreased growth in the corresponding normal and dwarf (autosomal dwarting gene) strains, characterized by normal plasma T3 levels, a result which agrees with the well-known adverse effects of thyroid hormone excess upon body growth.

Similarly, intra-uterine growth retarted lambs displayed T4 and T3 deficiencies during at least the first month of life (Wrutniak \& Cabello, 1987b; 1988). The administration of T3, three times a week, improved the growth rate of these animals by $25 \%$ during the first month of life (Cabello \& Wrutniak, unpublished results).

\section{SOME MECHANISMS OF ACTION OF THYROID HORMONES ON BODY GROWTH}

The purpose of this paper is not to review the complex metabolic effects of thyroid hormone included in the general mechanisms of body growth, such as the stimulation of protein synthesis in muscle (Brown, 1966; Goldberg, 1978) or influence on energy management (Van Hardeveld, 1986). In order to obtain valuable information on this topic, readers should refer to general reviews such as those of Ramsden (1977) or Van Hardeveld (1986). We have focused our attention on two aspects of thyroid hormone activity, the influence on growth factor production and the relationship to the regulation of the $\mathrm{GH}$ axis.

\section{Thyroid hormone stimulates growth factor production}

Although no significant influence of growth factors, such as nerve growth factor (NGF) or epidermal growth factor could be observed on in vivo growth rate, their potent mitogenic activity (Hollenberg, 1979) suggests a strong implication in the cellular mechanisms of growth and differentiation.

Numerous studies have shown that T4 increases NGF concentrations in the submandillary gland (Aloe \& Levy-Montaicini, 1980; Lakshmanan et al., 1984; Walker et al., 1981a) and in the brain (Walker et al., 1979; 1981b) of the neonatal or adult mouse. Moreover, Wion et al. (1985), 
using mouse L- cells, reported that T3 and $T 4$ were able to increase the cell level of NGF mRNA, suggesting that this influence is exerted by the control of NGF gene expression.

Similarly, in the same animal, thyroid hormone induces increased levels of EGF in the submandillary gland (Fisher et al, 1982; Gresik et al., 1981; Hosai et al., 1981; Walker et al., 1981a), the ocular tissue (Lakshmanan et al., 1985) or the skin (Hoath et al., 1983) during neonatal or adult life.

In addition, Hinkle \& Kinsella (1986) have shown that $T 3$ stimulated the production of an autocrine growth factor in pituitary tumor cells; this factor, with an apparent molecular weight of 50,000 , could be different from the growth factors identified today.

\section{T3 influences growth hormone and somatomedin production, and also their tissue activities}

Numerous studies have shown that thyroid hormone, especially $T 3$, influences the production and the physiological effects of $\mathrm{GH}$.

\section{T3 increases $\mathrm{GH}$ synthesis and secretion in mammals}

Today it is well-established that T3 influences synthesis and secretion of growth hormone on the basis of in vivo and in vitro studies.

In vivo, Wakabayashi et al. (1985) and Katakami et al. (1986) have shown that in thyroidectomized rats the amount of hypothalamic GRF was depressed, as was the sensitivity of pituitary somatotroph cells assessed by cyclic AMP and
GH accumulation after GRF stimulation. Similarly, rats treated by an antithyroid drug showed lowered pituitary and plasma $\mathrm{GH}$ concentrations, and a reduced response of these levels to GRF administration (Burstein et al., 1979; Dieguez et al., 1986; Kikuyama et al., 1974; Walker \& Dussault, 1980). The same data have been reported in rats developing a hypothyroid state consecutive to the administration of large doses of thyroxine (Pascual-Leone et al., 1976).

Several types of producing GH pituitary cell lines (GH1, GH3, GC) are convenient for studying the in vitro effects of thyroid hormone on $\mathrm{GH}$ production. In these cells, it has been shown that physiological amounts of $\mathrm{T} 3(\approx 2.5 \mathrm{nM})$ are able to stimulate the transcription of the GH gene, and also $\mathrm{GH}$ mRNA and $\mathrm{GH}$ accumulation (Dobner et al., 1981; Evans et al., 1982; Martial et al., 1977; Seo et al., 1977; Spindler et al., 1982). Moreover, the stimulation of gene transcription is dosedependent and occurs without a latency period (Yaffe \& Samuels, 1984). In fact, Casanova et al. (1985) have shown that this effect was mediated by the T3 nuclear receptor bound to a 5'-regulatory element of the $\mathrm{GH}$ gene.

However, in contrast to these results obtained in mammals or in mammals cells, it appears that thyroid hormone, and particularly T3, decreases both basal and TRH or GRF-induced $\mathrm{GH}$ secretion in chickens (Harvey, 1983; Scanes et al., 1986a; Scanes \& Harvey, 1989). This discrepancy needs further clarification in the species studied.

\section{T3 could influence the number of cell GH receptors}

As $\mathrm{GH}$ administration did not restore IGF levels in hypothyroid animals (Burstein et 
al., 1979), thyroid hormone could act at levels other than $\mathrm{GH}$ production sites in order to influence body growth. One of these sites of action could be the synthesis of $\mathrm{GH}$ receptors.

In the dwarf mouse, T3 administration over 4 weeks increased $\mathrm{GH}$ binding to hepatocytes four-fold (Fouchereau-Péron et al. 1981). However, Chernausek et al. (1982) reported that membranes of hepatocytes from thyroidectomized rats were able to bind higher amounts of $\mathrm{GH}$ than those from control animals, a result which was somewhat contradictory to the data of Fouchereau-Péron et al. (1981). Therefore, this aspect of thyroid hormone action needs clarification.

\section{T3 increases somatomedin production}

Whatever the mechanisms involved, T3 seems to increase somatomedin cell production. Thus, in vivo, in the dwarf mouse or in the hypophysectomized rat, $\mathrm{T} 4$ or $\mathrm{T} 3+\mathrm{GH}$ administration respectively increased or restored plasma levels of somatomedins (Holder \& Wallis, 1977; Schalch et al., 1979). On the other hand, in chickens, Decuypère et al. (1987) have shown that $\mathrm{MMl}$-induced hypothyroidism strongly reduced plasma somatomedin-C levels without influence on $\mathrm{GH}$ concentrations. In vitro, Binoux et al. (1985) observed that T3 stimulates insulin-like growth factor production by fetal hypothalamic cells. Taking into account all these results, it appears that T3 could increase autocrine or paracrine, as endocrine stimulation of growth by somatomedins.

\section{T3 influences the tissue activity of somatomedins}

This hypothesis, drawn from the work of Froesch et al. (1976) indicating that T3 is needed for a maximum stimulation of chick cartilage by somatomedins, needs further confirmation.

\section{CONCLUSIONS}

In this paper, we have shown that the socalled growth hormone does not always exert a positive influence upon IGF1 production and therefore upon general body growth. Moreover, it appears that its somatic effects are strongly dependent on thyroid status and particularly on T3 production. Therefore, it seems difficult to study $\mathrm{GH}$ regulation and physiological effects without taking into account this endocrine function.

In addition, we have stressed that T3 at least could be considered as a potent hormone affecting body growth, with not only specific effects, but also as a hormone able to potentiate GH and IGF1 activity. Thus it is quite surprising that, as in the case of $\mathrm{GH}$, systematic studies of modifications of T3 production have not been performed in order to stimulate growth performance in domestic animals. This could be due to the fact that thyroid hormone excess is as unfavourable as thyroid hormone deficiency, and that it is today very difficult to induce slight modifications in T3 production. This suggests that the study of accurate 
adjustments of T3 production could be an interesting field of research for improving body growth. In this purpose, two methods could be investigated:

The study of the regulation of type I and type II deiodinases involved in cellular T4 to T3 conversion, which are as yet poorly understood, could be a promising area for research. The half-life of these enzymes is short (about $30 \mathrm{~min}$ according to Leonard \& Visser, 1986) and in the future it is possible to imagine accurate manipulation of their activity. The recent cloning of one of these deiodinases (Boado et al., 1988) is an important step in this direction.

The identification of a factor inducing a short-term specific secretion of T3 by the thyroid gland (Cabello \& Wrutniak, 1988) could be another way to accurately adjust T3 production.

\section{REFERENCES}

Aloe L. \& Levy-Montaicini R. (1980) Comparative studies on testosterone and $L$-thyroxine effects on the synthesis of nerve growth factor in mouse submaxillary gland. Exp. Cell Res. $125,15-22$

Baile C.A., Della-Fera M.A. \& Buonomo F.C. (1985) Long-term treatment of cows, sheep and chickens with GRF : effects on plasma GH level and on growth and production. In : Therapeutic Agents Produced by Genetic Engineering. The Example of Growth Hormone and its Releasing Factor. Quo Vadis? Symposium, Sanofi group, May 20-30, Toulouse-Labège, France, pp. 359-370

Bakke J.L., Lawrence N.L., Robinson S. \& Bennett J. (1976) Lifelong alterations in endocrine function resulting from brief perinatal hypothyroidism in the rat. J. Lab. Clin. Med. 88 , 3-13

Balsam A. \& Ingbar S.H. (1979) Observations on the factors that control the generation of triiodothyronine from thyroxine in rat liver and the nature of the defect induced by fasting. $J$. Clin. Invest. 63, 1145-1156

Bass J.J., Gluckman P.D., Fairclough R.J., Petersen A.J., Davis S.R. \& Carter W.D. (1987) Effect of nutrition and immunization against somatostatin on growth and insulin-like growth factors in sheep. J. Endocrinol. 112, 27-31

Basset J.M., Thorburn G.D. \& Wallace A.L.C. (1970) The plasma growth hormone concentration in the fetal lamb. J. Endocrinol. 48, 251 . 263

Bassett N.S. \& Gluckman P.D. (1986) Pulsatile growth hormone secretion in the ovine fetus and neonatal lamb. J. Endocrinol. 109, 307-312

Baxter R.C., Bryson J.M. \& Turtle J.R. (1981) The effects of fasting on liver receptors for prolactin and growth hormone. Metabolism 30, 1086-1090

Bhakthavathsalan A., Mann L.I., Tang L.C., Erikson N.D., Delamater P.V. \& Damm C. (1981) The effects of fetal thyroidectomy during the second trimester in ovine fetus. Am. J. Obstet. Gynecol. 14, 436-442

Binoux M., Faivre-Bauman A., Lassarre C., Barret A. \& Tixier-Vidal A. (1985) Triiodothyronine stimulates the production of insulin-like growth factor (IGF) by fetal hypothalamus cells cultured in serum-free medium. Dev. Brain Res. 21, 319-321

Blum J.W., Gingins M., Vitins P. \& Bickel H. (1980) Thyroid hormone levels related to energy and nitrogen balance during weight loss and regain in adult sheep. Acta Endocrinol. 93, 440-447

Blum J.W. \& Kunz P. (1981) Effects of fasting on thyroid hormone levels and kinetics of reverse trilodothyronine in cattle. Acta Endocrinol. 98, 234-239

Boado R.J., Campbell D.A. \& Chopra I.J. (1988) Nucleotide sequence of rat liver iodothyronine $5^{\prime}$-monodeiodinase $\left(5^{\prime} \mathrm{MD}\right)$ : its identity with the protein disulfide isomerase. Biochem. Biophys. Res. Commun. 155, 1297-1304

Bowen S.J., Huybrechts L.M., Marsh J.A. \& Scanes C.G. (1987) Influence of triiodothyronine and growth hormone on growth of dwarf and normal chickens; interactions of hormone and genotype. Comp. Biochem. Physiol. 1, 137-142

Boyd R.D., Bauman D.E., Beerman D.H., De Neergard A.F., Souza L. \& Butler W.R. 
(1986) Titration of the porcine growth hormone dose which maximizes growth performance and lean deposition in swine. J. Anim. Sci. 63, 218

Brown D.M. (1966) Thyroxine stimulation of amino acid incorporation into protein of skeletal muscle in vitro. Endocrinology 78, 1252-1254

Burger A.G., Hughes J.N. \& Saville E. (1981) Starvation and thyroid function : effects on thermogenesis and serum thyrotropin. Life Sci. $28,1737-1744$

Burman K.D., Dimond R.C., Harvey G.S., O'Brian G.T., Georges L.P., Bruton J., Wright F.D. \& Wartotsky L. (1979) Glucose modulation of alterations in serum iodothyronine concentrations induced by fasting. Metabolism 28, 291-299

Burstein P.J., Draznin B., Johnson C.J. \& Schalch D.S. (1979) The effect of hypothyroidism on growth, serum growth hormone, the growth hormone-dependent somatomedin, insulin-like growth factor and its carrier protein in rats. Endocrinology 104, 1107-1111

Cabello G. \& Wrutniak C. (1988) Physiological approach of the mechanisms inducing the neonatal rises in plasma T4 and T3 levels in the lamb. In : Fetal and Neonatal Development (C.T. Jones, ed.), Perinatology Press, pp. 472477

Campbell R.G., Steele N.C., Caperna T.J., Mc Murtry J.P., Solomon M.B. \& Mitchell A.B. (1988) Interrelationships between energy intake and exogenous porcine growth hormone administration on the performance, body composition and protein and energy metabolism of growing pigs weighing 25 to 55 kilograms body weight. J. Anim. Sci. 66,1643 1655

Casanova J., Copp R.P., Janocko L. \& Samuels H.H. (1985) 5'-flanking of the rat growth hormone gene mediates regulated expression by thyroid hormone. J. Biol. Chem. $260,11744-11748$

Chernausek S.D., Underwood L.E. \& Van Wyk J.J. (1982) Influence of hypothyroidism on growth hormone binding by rat liver. Endocrinology 111, 1534-1538

Chopra I.J. (1980) Alterations in monodeiodination of iodothyronines in the fasting rat : effects of reduced non protein sulfhydryl groups and hypothyroidism. Metabolism 29, 161-167
Chung C.S., Etherton T.D. \& Wiggins J.P. (1985) Stimulation of swine growth by porcine growth hormone. J. Anim. Sci. 60, 118-130

Clark R.G. \& Robinson I.C.A.F. (1985) Growth induced by pulsatile infusion of an amidated fragment of human growth hormone releasing factor in normal and GHRF deficient rats. Nature 314, 281-283

Closset J., Maghuin-Rogister G., Tran Quang Minh O., Lambot \& Hennen G. (1986) Growth promotion in bulls using a synthetic vaccine against somatostatin. 12th, INRA Development Group Meeting, May 28-30, Montpellier

Cooke P.S., Yonemura C.U. \& Nicoll C.S. (1984) Development of thyroid hormone dependence for growth in the rat : a study involving transplanted fetal, neonatal and juvenile tissues. Endocrinology 115, 2059-2064

Decuypère E., Buyse J., Scanes C.G., Huybrechts C. \& Kuhn E.R. (1987) Effect of hyper- or hypothyroid status of broilers on growth, adiposity and levels of growth hormone, somatomedin-C and thyroid metabolism. Reprod. Nutr. Develop. 27, 555-565

Dieguez C., Jordan V., Harris P., Foord S., Rodriguez-Arnao M.D., Gomez-Pan A., Hall R. \& Scanion M.F. (1986) Growth hormone responses to growth hormone-releasing factor (1-29) in euthyroid, hypothyroid and hyperthyroid rats. J. Endocrinol. 109, 53-56

Dobner P.R., Kawasaki E.W., Yu L.Y. \& Bancroft F.C. (1981) Thyroid or glucocorticoid hormone induces pregrowth hormone mRNA and its probably nuclear precursor in rat pituitary cells. Proc. Natl. Acad. Sci. USA, 78, 2230-2234

Dubreuil P. \& Morisset J. (1986) Effects of somatocrinin and somatostatin antiserum on body and organ growth in the rat. Growth 50 , 325-339

Eguchi P. (1961) Atrophy of the fetal mouse adrenal following decapitation in utero: Endocrinology 68, 716-719

Erenberg A., Omori K., Oh W. \& Fisher D.A. (1973) The effect of fetal thyroidectomy on thyroid hormone metabolism in maternal and fetal sheep. Pediatr. Res. 7, 870-877

Erenberg A., Omori K., Menkes J.H., Oh W.H. \& Fisher D.A. (1974) Growth and development 
of the thyroitectomized ovine fetus. Pediatr. Res. 8, 783-789

Etherton T.D., Wiggins J.P., Chung C.S., Evock C.M., Rebhun J.F. \& Walton P.E. (1986) Stimulation of pig growth performance by porcine growth hormone and growth hormonereleasing factor. J. Anim. Sci. 63, 1389-1399

Etherton T.D., Wiggins J.P., Evock C.M., Chung C.S., Rebhun J.F., Walton P.E. \& Steele N.C. (1987) Stimulation of pig growth performance by porcine growth hormone : determination of the dose-response relationship. J. Anim. Sci. 64, 433-443

Evans R.M., Birnberg N.C. \& Rosenfeld M.G. (1982) Glucocorticoid and thyroid hormones transcriptionally regulate growth hormone gene expression. Proc. Natl. Acad. Sci. USA, 79, 7659-7663

Evock C.M., Etherton C.S., Chung C.S. \& Ivy R.E. (1988) Pituitary porcine growth hormone (pGH) and a recombinant $\mathrm{pGH}$ analog stimulate pig growth performance in a similar manner. J. Anim. Sci. 66, 1928-1941

Fabry J., Coert A., Ettaib A., Claes V. \& Ruelle L. (1985) Long term growth hormone treatment in bovines. Effects on plasmatic hormone levels, metabolite levels and on weight-gain. In : Therapeutic Agents Produced by Genetic Engineering. The Example of Growth Hormone and its Releasing Factor. "Quo Vadis ?" Symposium, Sanofi group, May 20-30, Toulouse-Labège, France, pp. 499-501

Fabry J., Claes V. \& Ruelle R. (1987) Influence de l'hormone de croissance sur la production de viande chez les génisses. Reprod. Nutr. Develop. 27, 591-600

Falconer J., Harvey S., Forbes J.M. \& Scanes C.G. (1981) Changes in somatomedin-like activity and growth hormone concentrations in the plasma of the domestic fowl (Gallus domesticus). Ajebak 59, 629-638

Fisher D.A., Dussault J.H., Sack J. \& Chopra I.J. (1977) Ontogenesis of hypothalamicpituitary-thyroid function and metabolism in man, sheep and rat. Rec. Progr. Horm. Res. 33, 59-116

Fisher D.A., Hoath S. \& Lakshmanan J. (1982) The thyroid hormone effect on growth and development may be mediated by growth factors. Endocrinol. Exp. 16, 259-271

Fouchereau-Péron M., Broer Y. \& Rosselin G. (1981) Triiodothyronine and growth hormone exert an opposite effect on the binding of growth hormone and insulin by hepatocytes from dwart mouse. Biochem. Biophys. Acta 677, 445-452

Frankenne F., Pirens G., Gomez F. \& Hennen G. (1987) Découverte d'un variant placentaire de l'hormone de croissance humaine : biochimie, physiologie et implication dans la secretion des formes hypophysaires. Reprod. Nutr. Develop. 27, 523-524

Frœesch E.R., Zapf J., Audhya T.K., Ben-Porath E., Segen B.J. \& Gibson K.B. (1976) Nonsuppressible insulin-like activity and thyroid hormones : major pituitary dependent sulphation factors for chick embryo cartilage. Proc. Natl. Acad. Sci. USA 73, 2904-2908

Gavin L.A. \& Moeller M. (1983) The mechanism of recovery of hepatic T4-5'-deiodinase during glucose-refeeding : role of glucagon and insulin. Metabolism 32, 543-551

Gluckman P.D. (1985) The onset and organization of hypothalamic control in the fetus. In : The Physiological Development of the Fetus and Newborn (C.T. Jones \& P.W. Nathanielsz, eds.), Academic Press, London, pp. 103-112

Gluckman P.D. \& Butler J.H. (1985) Insulin-like growth factors in the fetus. In : The Physiological Development of the Fetus and Newborn (C.T. Jones \& P.W. Nathanielsz, eds.), Academic Press, London, pp. 21-26

Goldberg A.L. (1978) Regulation of protein turnover in normal and dystrophic muscle. In : Pathogenesis of the Human Muscular Dystrophies (L.P. Rowland, ed.), Excerpta Medica, New York, p. 376

Grant D.B., Hambley J., Becker D. \& Pimstone B.L. (1973) Reduced sulfatation factor in undernourished children. Arch. Dis. Child. 48, 596-600

Gresik E.W., Schenkein 1., Van der None H. \& Barka T. (1981) Hormonal regulation of epidermal growth factor and protase in the submandibular gland of the adult mouse. Endocrinology 109, 924-929

Harvey S. (1983) Thyroid hormones inhibit growth hormone secretion in domestic fowls (Gallus domesticus). J. Endocrinol. 96, 329-334

Hinkle P.M. \& Kinsella P.A. (1986) Thyroid hormone induction of an autocrine growth factor secreted by pituitary tumor cells. Science 234, 1549-1552 
Hoath S.B., Lakshmanan J., Scott S.M. \& Fisher D.A. (1983) Effect of thyroid hormones on epidermal growth factor concentration in neonatal mouse skin. Endocrinology 112, 308313

Holder A.T. \& Wallis M. (1977) Actions of growth hormone, prolactin and thyroxine on serum somatomedin-like activity and growth in hypopituitary dwarf mice. J. Endocrinol. 74, 223-229

Hollenberg M.D. (1979) Epidermal growth factor-urogastrone, a polypeptid acquiring hormonal status. Vitam. Horm. 37, 69-110

Holt A.B., Cheek D.B. \& Kerr G.R. (1973) Prenatal hypothyroidism and brain composition in a primate. Nature $243,413-414$

Hopkins P.S. \& Thorburn G.D. (1972) The effects of fetal thyroidectomy on the development of the ovine fetus. J. Endocrinol. 54, 5556

Hosai K., Tanaka I. \& Veha T. (1981) Induction of epidermal growth factor by triodo-L-thyronine in the submandibular glands of mice with testicular feminization. J. Biochem. 90, 267-270

Hoshino S., Suzuki M., Kakegawa T., Wakita M. \& Kobayashi Y. (1986) Thyroid hormone response to thyrotrophin releasing hormone (TRH) in the sex-linked dwarf chicken. Endocrinol. Jpn. 33, 675-682

Hoshino S., Wakita M., Suzuki M. \& Yamamoto K. (1982) Changes in a somatomedin-like factor and immunoassayable growth hormone during growth of normal and dwarf pullets and cockerels. Poultry Sci. 61, 777-784

Hoshino S. \& Yamamoto K. (1977) Synthesis and release of growth hormone, prolactin, and other proteins from the anterior pituitary of normal and dwarf chickens. Gen. Comp. Endocrinol. 32, 7-16

Hughes J.N., Burger A., Pekary A.E. \& Hershman J.M. (1984) Rapid adaptation of serum thyrotrophin, triiodothyronine and reverse triiodothyronine levels to short-term starvation and refeeding. Acta Endocrinol. 105, 194-199

Huybrechts L.M., King D.B., Lauterio T.J., Marsh J.\& Scanes C.G. (1985) Plasma concentrations of somatomedin-C in hypophysectomized, dwarf and intact growing domestic fowl as determined by heterologous radioimmunoassay. J. Endocrinol. 104, 233-239
Huybrechts L., Künh E.R., Decuypère E., Mérat P. \& Scanes C.G. (1987) Plasma concentrations of growth hormone and somatomedin$\mathrm{C}$ in dwarf and normal chickens. Reprod. Nutr. Develop. 27, 547-554

Jones C.T., Rolph T.P., Lafeber H.N., Gu W., Harding J.E. \& Parer J.D. (1985) Experimental studies on the control of fetal growth. In : The Physiological Development of the Fetus and Newborn (C.T. Jones \& P.W. Nathanielsz, eds.) Academic Press, London, pp. 11-20

Jost A. (1969) Les relations hypothalamchypophysaires dans la période prénatale. Colloq. Nat. CNRS 927, 157-160

Jost A. (1977) Le rôle des hormones fœetales dans la croissance du fœetus. J. Physiol. (Paris) 73, 877-880

Jost A. \& Picon L. (1970) Hormonal control of fetal development and metabolism. $A d v$. Metab. Discov. 4, 123-183

Jost A., Picon L. \& Jacquot R. (1958) Influence de la thyroïdectomie du fœtus de lapin sur sa croissance et sur la teneur de son foie en lipides et glycogène. J. Physiol. (Paris) 50, 335338

Katakami H., Downs T.R. \& Frohman L.A. (1986) Decreased hypothalamic growth-hormone releasing hormone content and pituitary responsiveness in hypothyroidism. $J$. Clin. Invest. 77, 1704-1711

Kensinger R.S., Mc Munn L.M., Stover R.K., Schricker B.R., Macchecchini M.L., Harptster H.W. \& Kavanaugh J.F. (1987) Plasma somatotrophin response to exogenous growth hormone releasing factor in lambs. J. Anim. Sci. 64, 1002-1009

Kerr G.R., Tyson I.B., Allen J.R., Wallace J.H. \& Scheffler G. (1972) Deficiency of thyroid hormone and development of the fetal rhesus monkey. Biol. Neonate 21, 282-295

Kikuyama S., Nagasawa H., Yanai R. \& Yamanouchi K. (1974) Effect of perinatal hypothyroidism on pituitary secretion of growth hormone and prolactin in rats. J. Endocrinol. 62, 213-223

Klein A.H., Oddie T.H. \& Fisher D.A. (1978) Effect of parturition on serum iodothyronine concentrations in fetal sheep. Endocrinology 103, 1453-1457

Klein A.H., Oddie T.H. \& Fisher D.A. (1980) lodothyronine kinetic studies in the newborn lamb. J. Dev. Physiol. 2, 29-35 
Koritnik D.R., Humphrey W.D., Kaltenbach C.C. \& Dunn T.G. (1981) Effects of maternal undernutrition on the development of the ovine fetus and the associated changes in growth hormone and prolactin. Biol. Reprod. 24, 125137

Kühn E.R., Huybrechts L.M., Decuypere E. \& Mérat P. (1986a) Endocrinological effects of the sex-linked dwarf gene. III. Prolactin and growth hormone fail to increase the liver T4-5'monodeiodinase activity in the sex-linked dwarf chick embryo. World Poultry Science Association, 7 th Poultry Conference, Paris, pp. 960964

Kühn E.R., Verheyen G., Decuypère E., Huybrechts L. \& Iqbal A. (1986b) Growth hormone and thyrotropin-releasing hormone stimulate the peripheral conversion of thyroxine into triiodothyronine and the liver 5'-monodeiodinase activity in the adult chicken. IRCS Med. Sci. 14, 479 (abstr.)

Lakshmanan J., Beri U., Perheentupa J., Grueters A., Kim H., Mucaso T. \& Fisher D.A. (1984) Acquisition of submandibular gland nerve growth factor (SMG-NGF) responsiveness to thyroxine administration in neonatal mice. J. Neurosci. Res. 12, 71-85

Lakshmanan J., Perheentupa J., Hoath S.B., Kim H., Gruters A., Odell C. \& Fisher D.A. (1985) Epidermal Growth Factor in mouse ocular tissue : effects of thyroxine and exogenous epidermal growth factor. Pediatr. Res. 19, 315-319

Lascelles A.K. \& Setchell B.P. (1959) Hypothyroidism in sheep. Austr. J. Biol. Sci. 12, 445 . 465

Lassare C., Hardouin S., Daffos F., Forestier F. \& Binoux M. (1986) Etude des IGF et de leurs protéines de liaison au cours de la vie fotale chez l'homme. 12th Meeting, INRA Development Group, May 28-30, Montpellier

Lauterio T.J., Decuypère E. \& Scanes C.J. (1986) Growth protein synthesis and plasma concentrations of growth hormone, thyroxine and trilodothyronine in dwarf, control and growth-selected strains of broiler-type domestic fowl. Comp. Biochem. Physiol. 83A, 627-632

Leonard J.L. \& Visser T.J. (1986) Biochemistry of deiodination. In : Thyroid Hormone Metabolism (G. Hennemann, ed.), Marcel Dekker Inc., pp. 189-229
Leung F.C., Taylor J.E., Wien S. \& Van Iderstine A. (1986) Purified chicken growth hormone $(\mathrm{GH})$ and a human pancreatic $\mathrm{GH}$ releasing hormone increase body weight gain in the chicken. Endocrinology 118, 1961-1965

Leung F.C., Gillett J., Lilburn M.S. \& Kopchick J.J. (1987) Diminished hepatic growth hormone receptor binding in sex-linked dwarf broiler and leghorn chickens (42473). Proc. Soc. Exp. Biol. Med. 184, 234-238

Lowe K.C., Gluckman P.D., Jansen C.A.M. \& Nathanielsz P.W. (1986) Plasma growth hormone concentration in the chronically catheterized ovine fetus during spontaneous term delivery and premature delivery induced by continuous intravascular infusion of low doses of adrenocorticotropin or cortisol to the fetus. Am. J. Obstet. Gynecol. 154, 420-423

Maes M., Ketelslegers J.M. \& Underwood L.E. (1986) Low circulating somatomedin-C/insulinlike growth factor 1 in insulin-dependent diabetes and malnutrition : growth hormone receptor and post-receptor defects. Acta Endocrinol. 113, 86-92

Marsh J.A., Lauterio T.J. \& Scanes C.G. (1984) Effect of triodothyronine treatments on body and organ growth and the development of immune function in dwarf chicken. Proc. Soc. Exp. Biol. Med. 177, 82-91

Martial J.A., Baxter J.D., Goodman H.R. \& Seeburg P.H. (1977) Regulation of growth hormone messenger RNA by thyroid and glucocorticoid hormone. Proc. Natl. Acad. Sci. USA 74, 1816-1820

Marugo M., Bagnasco M., Contessini M., Bessarione D., Shenone F., Mignone D., Bernasconi D., Mazzochi D. \& Giusti M. (1984) Variations of thyroid hormones during total fasting in obese and in obese diabetic subjects. J. Endocrinol. Invest. 7, 197-200

May J.D. \& Marks H.L. (1983) Thyroid activity of selected, nonselected, and dwarf broiler lines. Poultry Sci. 62, 1721-1724

Moseley W.M., Krabill L.F., Friedman A.R. \& Olsen R.F. (1984) Extended treatment of steers with growth hormone-releasing factor (GRF), hpGRF 1-44 NH2 for five days. J. Anim. Sci. 59 (suppl. 1), 332 (abstr.)

Muir L.A., Wien S., Duquette P.F., Rickes E.L. \& Cordes E.H. (1983) The effects of exogenous growth hormone and dietylstilbestrol on growth 
and composition of growing lambs. J. Anim. Sci. 56, 1315-1323

Nagashima K., Yagi H.Y., Suzuki S., Noji T., Yunoki H. \& Kuroume T. (1986) Levels of growth and growth hormone releasing factor in cord blood. Biol. Neonate 49, 307-310

Parkes M.J. (1985) The transition between growth-hormone independent and growthhormone dependent growth. In : The Physiological Development of the Fetus and Newborn (C.T. Jones \& P.W. Nathanielsz, eds.) Academic Press, London, 55-58

Pascual-Leone A.M., Garcia M.D., Hervas F. \& Morreale de Escobare G. (1976) Decreased pituitary growth hormone content in rats treated neonatally with high doses of 1-thyroxine. Horm. Metab. Res. 8, 215-217

Pastoureau P., Barenton B., Blanchard M., Boivin G., Charrier J., Dulor J.P. \& Theriez M. (1988) Effects du GRF 1-29 chez l'agneau normal et hypotrophique. Reprod. Nutr. Develop. 28, 253-256

Petitclerc D., Pelletier G., Lapierre H., Gaudreau P., Couture Y., Dubreuil P., Morisset J. \& Brazeau P. (1987) Dose response of two synthetic human growth-hormone-releasing factors on growth hormone release in heifers and pigs. J. Anim. Sci. 65, 996-1005

Postel-Vinay M.C., Cohen T.E. \& Charrier J. (1982) Growth hormone receptors in rat liver membranes : effect of fasting and refeeding and correlations with plasma somatomedin activity. Mol. Cell. Endocr. 28, 657-669

Ramsden D.B. (1977) Peripheral Metabolism and Action of Thyroid Hormones (D.F. Horrobin, ed.), Eden Press, vol. 2, pp. 294

Röjdmark S. \& Nygren A. (1983) Thyrotropin and prolactin responses to thyrotropin-releasing hormone : influence of fasting- and insulininduced changes in glucose metabolism. Metabolism 32, 1013-1018

Sara V.R. \& Carlsson-Skwirut C. (1986) The biosynthesis of somatomedins and their role in the fetus. Acta Endocrinol. 113 (suppl. 279), 82-85

Scanes C.G. \& Harvey S. (1989) Triiodothyronine inhibition of thyrotropin-releasing hormone and growth-hormone-releasing factorinduced growth hormone secretion in anesthetized chickens. Gen. Comp. Endocrinol. 73, 477-484
Scanes C.G., Marsh J., Decuypère E. \& Rudas P. (1983) Abnormalities in the plasma concentrations of thyroxine, triiodothyronine and growth hormone in sex linked dwarf and autosomal dwarf white leghorn domestic fowl (Gallus domesticus). J. Endocrinol. 97, 127-135

Scanes C.G., Denver R.J., Bowen S.J. (1986a) Effect of thyroid hormones on growth hormone secretion in broiler chickens. Poult. Sci. 65, 384-390

Scanes C.G., Duyka D.R., Lauterio D.J., Bowen S.J., Huybrechts L.M., Bacon W.M. \& King D.B. (1986b) Effect of chicken growth hormone, triiodothyronine and hypophysectomy in growing domestic fowl. Growth 50, 12-31

Schalch D.S., Heinrich U.E., Draznin B., Johnson C.J. \& Miller L.L. (1979) Role of the liver in regulating somatomedin activity : hormonal effects on the synthesis and release of insulin-like growth factor and its carrier protein by the isolated perfused rat liver. Endocrinology 104, 1143-1151

Seo H., Vassart G., Brocas H. \& Refetoff S. (1977) Triiodothyronine stimulates specifically GH mRNA in rat pituitary tumor cells. Proc. Natl. Acad. Sci. USA 74, 2054-2058

Setchell B.P., Dickinson D.A., Lascelles A.K. \& Bonner R.B. (1960) Neonatal mortality in lambs associated with goitre. Austr. Vet. J. 36, 159164

Spindler S.R., Mellon S.H. \& Baxter J.D. (1982) Growth hormone gene transcription is regulated by thyroid and glucorticoid hormones in cultured rat pituitary tumor cells. J. Biol. Chem. 257, 11627-11632

Suda A.K., Pittman C.S., Shimizu T. \& Chambers J.B. (1978) The production and metabolism of $3,5,3^{\prime}$-triiodothyronine and $3,3^{\prime}, 5^{\prime}$ triiodothyronine in normal and fasting subjects. J. Clin. Endocrinol. Metab. 47, 1311-1319

Tveit B. \& Almlid T. (1980) T4 degradation rate and plasma levels of TSH and thyroid hormones in ten young bulls during feeding conditions and $48 \mathrm{~h}$ of starvation. Acta Endocrinol. 93, 435-439

Tveit B. \& Larsen F. (1983) Suppression and stimulation of TSH and thyroid hormones in bulls during starvation and refeeding. Acta Endocrinol. 103, 223-226

Utiger R.D. (1979) Hypothyroidism. In : Endocrinology (L.J. De Groot et al., eds.), 
Grune \& Stratton, inc. New York, vol. 1, pp. 471-488

Van Hardeveld C. (1986) Effects of thyroid hormone on oxygen consumption, heat production, and energy economy. In : Thyroid Hormone Metabolism (G. Henneman, ed.), M. Dekker Inc., pp. 579-608

Vezhinet A. (1968) Effets de l'hypophysectomie sur la croissance pondérale du lapin. $C R$ Acad. Sci. Sér. D. 266, 2348-2351

Wagner J.F. \& Veenhuizen E.L. (1978) Growth performance, carcass deposition and plasma hormone levels in weather lambs when treated with growth hormone and thyroprotein. J. Anim. Sci. 47 (suppl. 1), 397 (abstr.)

Wakabayashi I., Tonegawa Y., Ihara T., Hattori M., Shibasaki T. \& Ling L. (1985) Plasma growth hormone response to human growth hormone releasing factor in rats administered with chlorpromazine and antiserum against somatostatin. Effects of hypo- and hyperthyroidism. Neuroendocrinology 41, 306-311

Walker D.G., Simpson M.E., Asling C.W. \& Evans H.M. (1950) Growth and differentiation in the rat following hypophysectomy at 6 days of age. Anat. Rec. 106, 539-554

Walker P. \& Dussault J.H. (1980) Hypothalamic somatostatin and pituitary and serum growth hormone concentrations during postnatal development in rats exposed chronically to propylthiouracil or a low iodine diet. J. Dev. Physiol. 2, 11-117

Walker P., Weischel M.E., Guo J.M. \& Fisher D.A. (1979) Thyroxine increases nerve growth factor concentrations in adult mouse brain. Science 204, 427-429

Walker P., Weischel M.E., Hoath S.R., Poland R.E. \& Fisher D.A. (1981a) Effect of thyroxine, testosterone and corticosterone on nerve growth factor (NGF) and epidermal growth factor (EGF) concentrations in adult female mouse submaxillary gland : dissociation of NGF and EGF responses. Endocrinology 109, 582-587

Walker P., Weil M.L., Weischel M.E. \& Fisher D.A. (1981b) Effect of thyroxine on nerve growth factor concentration in neonatal mouse brain. Life Sci. 28, 1777-1787

Wehrenberg W.B. (1986) The role of growthhormone-releasing factor and somatostatin on somatic growth in rats. Endocrinology 118, 489494

Wheatley I.S., Wallace A.L.C. \& Bassett J.M. (1966) Metabolic effects of ovine growth hormone in sheep. J. Endocrinol. 35, 341-353

Wion D., Barrand P., Dicou E., Scott J.\& Brachet P. (1985) Serum thyroid hormones T3 and $\mathrm{T} 4$ regulate nerve growth factor mRNA levels in mouse L-cells. FEBS Letters 189, 3741

Wrutniak C. \& Cabello G. (1983) Changes in the concentration of thyroxine in the plasma of rat fetuses during late gestation : influence of ligation of the maternal uterine vein and artery. J. Endocrinol. 99, 233-238

Wrutniak C. \& Cabello G. (1987a) Effects of food restriction on the concentrations of cortisol, TSH and iodothyronines in the plasma of the newborn lamb. Reprod. Nutr. Dev. 27, 721-732

Wrutniak C. \& Cabello G. (1987b) Neonatal changes in plasma cortisol, free and total iodothyronine levels in control and hypotrophic lambs. Reprod. Nutr. Dev. 27, 945-953

Wrutniak C. \& Cabello G. (1988) Neonatal thyroid function in the hypotrophic lamb. In : Fetal and Neonatal Development (C.T. Jones ed.), Perinatology Press, pp. 491-495

Wrutniak C., Cabello G. \& Bosc M. (1985) Plasma free and total iodothyronines levels in hypophysectomised and intact lamb foetuses during the last third of gestation. Acta Endocrinol. 110, 388-394

Wu S.Y., Polk D.H., Klein A.H. \& Fisher D.A. (1986) The mechanism of low serum T3 in the fetus : hepatic T4-5'-monodeiodinase versus tissue sulfhydryl content. A clarification. $J$. Dev. Physiol. 8, 43-47

Yaffe B.M. \& Samuels H.H. (1984) Hormonal regulation of the growth hormone gene : relationship of the rate of transcription to the level of nuclear thyroid hormone-receptor complexes. J. Biol. Chem. 259, 6284-6291 